\title{
PENGGUNAAN LEMBAR KERJA MAHASISWA TERBIMBING BERBASIS INQUIRY PADA MATA KULIAH PENINGKATAN KETERAMPILAN BERBAHASA INDONESIA (PKBI) UNTUK MENGEMBANGKAN KARAKTER MAHASISWA PGSD IKIP PGRI MADIUN
}

\author{
Dewi Tryanasari *
}

\begin{abstract}
Every teacher must foster the positive attitude, all the more, those of elementary schools. This kind of positive attitude should be cultivated since they are still studying in the teacher training study program. The students of elementary school teacher training study program of IKIP PGRI MADIUN have not yet coped with the positive attitude well, which is shown through evidence that they have not yet foster self-discipline in many class activities, such as being late getting in class, being incomplete doing tasks, being insensitive against the environmental changes and phenomena. In effort of cultivating their positive mental attitude, this research is conducted in the form of class action research design by inquirybased controlled student worksheet. The student worksheet is used to develop the inquiry learning process for the mental attitude development, and the lecturer's control is used to develop the linguistic and to nurture the concepts. As the nature of classroom action researh is to overcome problems, this research is conduted for the most problematic class of all, i.e. class $2 G$. The analysis results in conclusions that the positive attitude of the students develops in terms of self-discipline and learning activity, so as to suggest that inquiry-based controlled student worksheet is effective to develop students mental attitude.
\end{abstract}

Key words: Student Worksheet, Indonesian Language Skill, Positive Attitude Development

\begin{abstract}
Abstrak
Karakter positif harus dimiliki oleh seorang guru terutama guru sekolah dasar (SD) yang menjadi ujung tombak pendidikan dasar. Pembentukan karakter positif pada calon guru SD seharusnya dimulai dari proses perkuliahan. Gejala yang ditunjukkan oleh mahasiswa semester 2 Prodi PGSD IKIP PGRI Madiun adalah kurangnya karakter positif yang terbukti dengan banyaknya mahasiswa yang terlambat dalam mengikuti proses perkuliahan,
\end{abstract}

* Dewi Tryanasari adalah Dosen Prodi PGSD IKIP PGRI Madiun 
mengumpulka tugas, dan kurang proaktifnya mahasiswa terhadap perkembangan yang terjadi dalam dunia kampus. Untuk itu diperlukan penyelesaian masalah melalui penelitian tindakan yang secara umum bertujuan untuk mengembangkan karakter. Lembar Kerja Mahasiswa (LKM) sebagai salah satu sarana perkuliahan dipilih sebagai alternatif pemecahan masalah. LKM yang dimaksud dalam penelitian ini adalah LKM terbimbing berbasis inquiry sehingga dalam proses perkuliahan mahasiswa dapat menemukan konsep secara mandiri kemudian proses pembimbingan dilakukan untuk meluruskan konsep yang salah serta melakukan praktik secara langsung untuk memupuk keterampilan berbahasa mahasiswa. Karena penelitian yang digunakan untuk memecahkan masalah adalah penelitian tindakan kelas, maka dalam penelitian ini diambil kelas yang paling bermasalah dalam hal karakter. Berdasarkan pengamatan awal, kelas yang paling bermasalah dalam hal ini adalah kelas 2G. Hasil penelitian menunjukkan bahwa setelah proses perkuliahan dengan LKM ini berlangsung, mahasiswa yang semula diindikasikan bermasalah dalam hal disiplin dan keaktifan menunjukkan perkembangan disiplin dan keaktifan yang baik. Hal ini menunjukkan bahwa penggunaan LKM terbimbing berbasis inquiry memang efektif untuk mengembangkan karakter.

Kata Kunci: Karakter, Lembar Kerja Mahasiswa

\section{A. PENDAHULUAN}

Bahasa Indonesia adalah salah satu mata pelajaran yang diajarkan di jenjang sekolah dasar (SD). Dalam pembelajaran Bahasa Indonesia ada empat aspek yang saling berkaitan dan tidak dapat dipisahkan pada konteks kehidupan nyata, yaitu: aspek keterampilan menyimak, berbicara, membaca, dan menulis. Setiap keterampilan tersebut saling berhubungan. Keterampilan menyimak dan keterampilan membaca yang merupakan keterampilan berbahasa yang bersifat reseptif, mendasari keterampilan menulis dan berbicara yang merupakan keterampilan produktif. Keterampilan berbahasa muncul secara berurutan. Dimulai dari aspek menyimak bahasa kemudian berbicara, sesudah itu pada tahap berikutnya belajar membaca dan menulis. Keterampilan menyimak dan keterampilan berbicara dapat dipelajari sebelum memasuki masa sekolah, sedangkan keterampilan membaca dan keterampilan menulis dapat dipelajari pada masa sekolah atau berada di lingkungan sekolah. Keempat keterampilan tersebut pada dasarnya merupakan suatu kesatuan yaitu catur tunggal (Tarigan, 2008:1).

Bahasa tidak boleh hanya dipandang sebagai seperangkat kaidah, tetapi harus dipandang sebagai sarana untuk berkomunikasi. Oleh karena itu pembelajaran Bahasa Indonesia sebaiknya diarahkan pada penguasaan keterampilan menyimak, berbicara, membaca dan menulis, bukan hanya penguasaan terhadap aturan menyimak, berbicara, membaca, dan menulis. Penguasaan keempat keterampilan berbahasa tersebut, hanya dapat diperoleh dan dikuasai dengan jalan praktik, latihan yang intensif, dan bimbingan yang 
sistematis. Dengan melatih keterampilan berbahasa seseorang, maka keterampilan berpikir seseorang secara otomatis akan terasah (Tarigan, 2008:3).

Matakuliah Peningkatan Keterampilan Berbahasa Indonesia yang disingkat PKBI adalah salah satu matakuliah wajib yang harus ditempuh oleh mahasiswa program studi PGSD IKIP PGRI MADIUN. Dalam mata kuliah ini, mahasiswa dituntut untuk menguasai keterampilan berbahasa baik menyimak, membaca, berbicara, maupun menulis. Produk akhir perkuliahan ini adalah mahasiswa mahir dalam menyimak, membaca, berbicara dan menulis dengan menggunakan berbagai macam strategi . Hal ini, akan memberikan gambaran nyata tentang bagaimana keempat keterampilan berbahasa tersebut bisa diajarkan secara bervariasi sekaligus meningkatkan keterampilan mahasiswa dalam menyimak, membaca, berbicara, dan menulis.

Di era globalisasi multidimensional saat ini yang disertai dengan persaingan tajam antar Negara dan antar wilayah di dunia, sangat terasa apa yang dinamakan "human and national capabilities" agar Negara-negara di dunia tidak hanya memiliki keunggulan komparatif (comparative advantage), melainkan juga menguasai keunggulan kompetitif (competitive advantage) yang merupakan refleksi daya saing di segala aspek kehidupan (competitiveness $=$ a comparative concept of the ability and performance), sebagai parameter keberadaban (civilization) suatu bangsa. Mengingat sains dan teknologi merupakan kunci peradaban, maka negara-negara di dunia berlomba untuk menguasai hi-tech yang bersumber dari pendidikan dan riset unggul. Berbagai hasil penemuan kemajuan dilindungi oleh hukum baik nasional maupun internasional (WTO - TRIPS $=$ The Agreement on Trade Related Aspects of IPRs) yang mengatur standard minimum bentuk-bentuk regulasi atas hak atas kekayaan intelektual (intellectual property rights) berupa hak cipta, paten, merek, produk desain industri, dan integrated circuit layout- design.

Pertumbuhan ekonomi, peningkatan mutu pendidikan, serta kemajuan sains dan teknologi yang berinteraksi dengan nilai-nilai sosial, budaya dan agama, merupakan alat penting yang memiliki uleverage effect terhadap kemajuan parameter keberadaban yang lain, seperti tinggi rendahnya tingkat pengangguran, kemiskinan, kualitas infrastruktur, kemampuan untuk menarik modal asing (FDI), peningkatan produktivitas nasional, terciptanya nilai tambah di berbagai bidang, pertumbuhan industri yang berorientasi ekspor, peningkatan harkat dan martabat bangsa di mata internasional dan sebagainya. Dengan ilmu pengetahuan dan teknologi kita dapat menjelaskan (to explain), menggambarkan (to describe) segala kenyataan atau fakta secara lebih lengkap dan jelas, mengungkap (to reveal) segala hal yang ada di belakang fakta dan memperkirakan (to predict) apa yang akan terjadi di masa depan secara terukur (measurable) dan memberikan alternatif penyelesaian masalah secara obyektif serta penciptaan nilai tambah. Namun demikian, pengembangan kebijakan, sains, dan teknologi dalam bidang struktur dan substansi tidak cukup, tanpa dilengkapi dengan budaya iptek (pandangan, sikap, perilaku, persepsi, dan filosofi) yang penuh dengan nuansa etika dan moral, sekaligus hak asasi manusia (HAM) dalam kerangka sistem dan kehidupan demokrasi, agar supaya keunggulan sain dan teknologi tersebut justru 
tidak menjadi bumerang dan tidak kontraproduktif bagi umat manusia, dalam arti merugikan bahkan dapat menimbulkan bencana bagi kemanusiaan.

Guru merupakan ujung tombak pendidikan yang berperan sebagai motivator dan fasilitator dalam proses pendidikan. Untuk bisa menjadi motivator dan fasilitator yang baik, seorang guru dituntut memiliki karakter mandiri, kritis, kreatif, bertanggungjawab,dan disiplin. Karakter baik yang melekat pada guru sebagai motivator dan fasilitator pendidikan, tidak lepas dari proses pembentukan karakter yang dijalani oleh seorang calon guru sebelum dia terjun ke lapangan. Untuk itu, pendidikan, pelatihan, dan pengajaran yang diberikan kepada seorang calon guru harus mengarah pada pembentukan karakter positif yang sangat diperlukan ketika mereka sudah turun ke lapangan.

Hal yang sama juga berlaku untuk guru SD. Menurut Piaget (1950) anak usia sekolah dasar berada pada tahapan operasi konkret. Pada rentang usia sekolah dasar tersebut anak mulai menunjukkan perilaku belajar yakni: (1) mulai memandang dunia secara objektif, bergeser dari satu aspek situasi ke aspek lain secara reflektif dan memandang unsur-unsur secara serentak; (2) mulai berpikir secara operasional; (3) mempergunakan cara berpikir operasional untuk mengklasifikasikan benda-benda; (4) membentuk dan mempergunakan keterhubungan aturan-aturan, prinsip ilmiah sederhana, dan mempergunakan hubungan sebab akibat; dan (5) memahami konsep substansi, volume zat cair, panjang, lebar, luas, dan berat.

Memperhatikan tahapan perkembangan berpikir tersebut, kecenderungan belajar anak usia sekolah dasar memiliki tiga ciri, yaitu: (1) konkret, mengandung makna proses belajar beranjak dari hal-hal yang konkrit yakni yang dapat dilihat, didengar, dibaui, diraba, dan diotak- atik, dengan titik penekanan pada pemanfaatan lingkungan sebagai sumber belajar. Pemanfaatan lingkungan akan menghasilkan proses dan hasil belajar yang lebih bermakna dan bernilai, sebab siswa dihadapkan dengan peristiwa dan keadaan yang sebenarnya, keadaan yang alami, sehingga lebih nyata, lebih faktual, lebih bermakna, dan kebenarannya lebih dapat dipertanggungjawabkan; (2) integratif, pada tahap usia sekolah dasar anak memandang sesuatu yang dipelajari sebagai suatu keutuhan, mereka belum mampu memilah-milah konsep dari berbagai disiplin ilmu, hal ini melukiskan cara berpikir anak yang deduktif yakni dari hal umum ke bagian demi bagian; dan (3) hierarkis, pada tahapan usia sekolah dasar, cara anak belajar berkembang secara bertahap mulai dari hal-hal yang sederhana ke hal-hal yang lebih kompleks.

Bertitik tolak dari karakteristik belajar anak SD tersebut, guru sebagai motivator dan fasilitator dalam pembelajaran dituntut untuk mampu menjadi model yang ideal bagi anak sekaligus mampu menghubungkan materi pembelajaran yang diberikan dengan kebutuhan anak di lingkungan. Selain itu guru Sekolah Dasar juga dituntut untuk mampu menunjukkan jalan termudah kepada anak sehingga, anak mampu mengkonstruk pengetahuannya serta mengalami proses pembelajaran yang bermakna. Untuk menciptakan guru SD yang berkarakter seperti di atas akan sangat mustahil jika calon guru SD pada proses pembelajarannya tidak melalui proses pembelajaran yang bermakna. Pepatah mengatakan bahwa "pengalaman adalah guru yang terbaik", untuk itu calon Guru SD, sebelum mampu terjun ke lapangan dan menjadi motivator serta 
fasilitator yang baik harus mengalami dulu proses pembelajaran yang bernuansa konstruktivisme dan menuntut calon guru tersebut untuk mandiri, kreatif, kritis, bertanggungjawab, dan disiplin.

Untuk dapat membangun sistem pembelajaran yang bernuansa konstruktivisme dan menuntut calon guru Sekolah Dasar untuk mandiri, kreatif, kritis, bertanggung jawab, dan disiplin, perlu adanya rancangan perkuliahan pada mahasiswa Prodi PGSD yang menuntut partisipasi aktif mahasiswa dalam perkuliahan. Rancangan yang dimaksud adalah rancangan perkuliahan dengan menggunakan Lembar Kerja Mahasiswa (LKM) berbasis konstruktivisme sebagai sarana penunjang perkuliahan. Dengan penggunaan LKM diharapkan mahasiswa mampu melaksanakan perkuliahan secara mandiri di luar jam tatap muka dengan dosen. LKM yang akan diterapkan berisi pertanyaan-pertanyaan yang harus dijawab mahasiswa dengan teori yang bersumber dari berbagai macam sumber. Hal ini merupakan tugas mandiri yang harus dikerjakan mahasiswa di luar jam perkuliahan. Dengan demikian mahasiswa dipaksa untuk secara mandiri membaca dan menelaah berbagai macam sumber yang terkait dengan pertanyaan.

Selain itu LKM juga berisi lembar review yang berfungsi untuk mengecek kebenaran pemahaman mahasiswa terhadap konsep yang ditanyakan ketika bertatap muka dengan dosen. Dalam mereview, dosen tidak akan begitu saja memberikan konsep melainkan mengkroscek pendapat mahasiswa yang satu dengan yang lain sehingga terjadi interaksi antar mahasiswa pada saat proses pembelajaran secara terbimbing dan terstruktur. Hal ini tentunya akan memupuk toleransi dan menghargai antar mahasiswa sekaligus mampu membelajarkan mahasiswa untuk berbicara secara kritis. Selanjutnya dari teori tersebut, mahasiswa mempraktikkan empat keterampilan berbahasa melalui lembar praktik yang langkah-langkahnya tersusun dalam LKM. Dengan demikian melalui pengerjaan LKM karakter mandiri, bertanggung jawab, dan proaktif akan terbentuk pada diri mahasiswa. Bertitik tolak dari penjelasan di atas maka Penggunaan Lembar Kerja Mahasiswa (LKM) Terbimbing Berbasis Inquiry pada Matakuliah Peningkatan Keterampilan Berbahasa Indonesia (PKBI) untuk Mengembangkan Karakter Mahasiswa PGSD IKIP PGRI Madiun perlu dilakukan.

Mahasiswa semester 2 di Prodi IKIP PGRI Madiun, secara umum masih bermasalah dalam hal karakter. Dari pengamatan awal, kelas yang paling bermasalah dalam karakter adalah kelas 2G. Hal ini ditunjukkan dengan: (1) banyaknya persentase keterlambatan mahasiswa saat mengikuti perkuliahan meskipun di awal perkuliahan sudah diadakan kontrak perkuliahan yang jelas oleh dosen; (2) rendahnya kesadaran mahasiswa untuk melakukan tugas mandiri yang telah diberikan, terbukti dengan sering terlambatnya sebagian besar mahasiswa kelas 2G dalam mengumpulkan tugas; (3) kurangnya kepedulian mahasiswa terhadap lingkungan terbukti dengan banyak sekali info yang terlewatkan oleh kelas tersebut ketika ketua kelas berhalangan hadir atau dosen wali tidak menyampaikan secara lisan meskipun pengumuman sudah ditempel secara tertulis; dan (4) kurangnya kepedulian mahasiswa terhadap kelangsungan perkuliahan dan kerjasama atau kekompakan kelas, terbukti dengan untuk meminjam LCD ke Prodi sebagai sarana perkuliahan atau persentasi hanya 
mahasiswa tertentu yang selalu mengusahakan (ketua kelas dan sekretaris kelas) sementara untuk kelompok yang persentasi justru hanya saling perintah tanpa action nyata. Seluruh masalah yang terjadi di kelas tersebut, menunjukkan bahwa karakter positif yang seharusnya dimiliki oleh seorang mahasiswa belum tertanam dengan baik. Oleh karena itu perlu dilakukan pengkajian mendalam melalui penelitian untuk mengatasi masalah yang terjadi.

Agar masalah yang dibahas fokus dan mendalam maka dirumuskan rumusan masalah, yakni: (1) bagaimana proses perencanaan penggunaan LKM terbimbing berbasis inquiry pada mata kuliah PKBI untuk mengembangkan karakter mahasiswa semester 2 Prodi PGSD IKIP PGRI Madiun? (2) bagaimana proses pelaksanaan penggunaan LKM terbimbing berbasis inquiry pada mata kuliah PKBI untuk mengembangkan karakter mahasiswa mahasiswa semester 2 PGSD IKIP PGRI Madiun? (3) bagaimana perkembangan karakter mahasiswa semester 2 PGSD IKIP PGRI Madiun setelah penggunaan LKM terbimbing berbasis inquiry pada mata kuliah PKBI? Selaras dengan rumusan masalah tersebut, penelitian ini bertujuan untuk: (1) mendeskripsikan terbimbing berbasis inquiry pada mata kuliah PKBI untuk mengembangkan karakter mahasiswa semester 2 Prodi PGSD IKIP PGRI Madiun; (2) mendeskripsikan pelaksanaan pembelajaran Mata Kuliah PKBI dengan menggunakan LKM terbimbing berbasis inquiry untuk mengembangkan karakter mahasiswa semester 2 Prodi PGSD IKIP PGRI Madiun; dan (3) mendeskripsikan perkembangan karakter mahasiswa semester 2 Prodi PGSD IKIP PGRI Madiun setelah penggunaan LKM terbimbing berbasis inquiry pada mata kuliah PKBI.

\section{B. KAJIAN PUSTAKA}

\section{Pembelajaran Bahasa Indonesia}

Tarigan, dkk. (2005:16) menyatakan bahwa pembelajaran adalah pengalaman belajar yang dialami siswa dalam proses mencapai tujuan khusus pembelajaran. Sadiman berpendapat bahwa pembelajaran adalah usaha-usaha yang terencana dalam memanipulasi sumber-sumber belajar agar terjadi proses belajar dalam diri peserta didik (Warsita, 2008:85). Sementara itu Miarso pembelajaran disebut juga kegiatan pembelajaran (instruksional) adalah usaha mengelola lingkungan dengan sengaja agar seseorang membentuk diri secara positif dalam kondisi tertentu (Warsita, 2008:85). Sedang menurut Depdiknas pembelajaran adalah proses interaksi peserta didik dengan pendidik dan sumber belajar pada suatu lingkungan belajar (Warsita, 2008:85). Dengan demikian, pembelajaran adalah segala upaya yang dilakukan pendidik agar terjadi proses belajar pada siswa untuk mencapai tujuan pembelajaran.

Pada hakikatnya belajar bahasa adalah belajar berkomunikasi. Oleh karena itu, pengajaran bahasa di SD menggunakan pendekatan komunikatif. Pembelajaran-pembelajaran bahasa indonesia di SD diarahkan untuk meningkatkan kemampuan siswa dalam berkomunikasi dengan bahasa Indonesia baik secara lisan maupun tertulis. Hal ini berarti belajar bahasa berarti belajar berkomunikasi (Tarigan, dkk. 2001:3.31). Menurut Tarigan, dkk. (2005:17), karakteristik pembelajaran bahasa Indonesia adalah:

a. Setiap pembelajaran bahasa Indonesia berupa kegiatan siswa; 
b. Setiap pembelajaran berkaitan dengan kegiatan berbahasa seperti menyimak, berbicara, membaca, atau menulis sebagai fokusnya;

c. Setiap pembelajaran dimulai dengan kata kerja;

d. Setiap pembelajaran dapat dikembangkan secara kreatif;

e. Setiap pembelajaran berkaitan dengan komponen PBM dan pendekatan CBSA, ketrampilan proses serta pendekatan komunikatif.

Menurut Slamet (2008:6) pengajaran bahasa Indonesia pada hakikatnya adalah pengajaran keterampilan berbahasa, bukan pengajaran tentang bahasa. Tata bahasa, kosakata dan sastra disajikan dalam konteks, yaitu dalam kaitannya dengan keterampilan tertentu yang tengah diajarkan bukan sebagai pengetahuan tata bahasa, teori pengembangan kosakata, teori sastra sebagai pendukung atau alat penjelas. Sedangkan menurut Nurhadi (2004:193), pengajaran bahasa bertujuan agar pembelajar atau siswa mampu berkomunikasi dalam bahasa Indonesia. Kemampuan berbahasa nyata harus menjadi tujuan utama pengajaran bahasa Indonesia. Anak-anak diharapkan dapat membaca, menulis, berbicara dan mendengarkan dengan baik. Pembelajaran Bahasa dan Sastra Indonesia diarahkan untuk meningkatkan kemampuan siswa dalam berkomunikasi dalam berbahasa secara lisan dan tertulis. Menurut Departemen Pendidikan dan Kebudayaan ruang lingkup mata pelajaran bahasa dan sastra Indonesia meliputi penguasaan kebahasaan, kemampuan memahami dan mengapresiasi sastra, serta kemampuan menggunakan bahasa Indonesia (Sumardi, 2000:35). Suparno menjelaskan bahwa komponen (ruang lingkup) berisi penegasan bahwa pengajaran Bahasa Indonesia adalah pengajaran keterampilan berbahasa, baik reseptif maupun produktif (Mulyati, 1999:3.6). Tata bahasa, kosakata, dan sastra disajikan dalam konteks. Pada dasarnya yang harus dibinakan kepada siswa dalam komponen ruang lingkup adalah keterampilan berbahasa, baik yang berbentuk reseptif maupun produktif secara terpadu.

Keterampilan berbahasa reseptif adalah keterampilan menerima pesan/ide atau gagasan dari orang lain dalam bentuk lisan maupun tulisan. Sedangkan keterampilan bahasa produktif adalah keterampilan menyampaikan pesan/ide atau gagasan kepada orang lain dalam bentuk lisan maupun tulisan. Dengan demikian, keterampilan reseptif terdapat pada keterampilan menyimak dan membaca, dan jenis keterampilan produktif terdapat pada keterampilan membaca dan menulis (Mulyati, 2000:37). Hakikat pengajaran bahasa Indonesia adalah keterampilan berbahasa Indonesia, bukan pengajaran tentang bahasa atau struktur bahasa. Pengetahuan bahasa dan sastra berkedudukan sebagai penunjang atau penjelas dalam keterampilan berbahasa dan apresiasi karya sastra.

Fungsi bahasa yang utama adalah sebagai alat komunikasi. Oleh karena itu, pembelajaran bahasa harus ditekankan pada pemanfaatan bahasa sebagai alat komunikasi bukan sebagai ilmu. Pembelajaran bahasa Indonesia diusahakan bermakna dengan memaksimalkan fungsi bahasa itu sendiri dalam kehidupan sehari-hari, sehingga siswa bisa menggunakan pengetahuan yang dimilikinya sebagai modal awal dalam kehidupan. Interaksi antara siswa dan guru dalam pengajaran bahasa Indonesia didasrkan pada penempatan siswa sebagai subjek 
belajar bukan sebagai objek. Oleh karena itu siswa dituntut untuk berperan aktif dalam proses kegiatan belajar mengajar.

\section{Matakuliah Peningkatan Keterampilan Berbahasa Indonesia}

Matakuliah PKBI adalah salah satu mata kuliah yang wajib ditempuh oleh mahasiswa PGSD. Mata Kuliah ini merupakan mata kuliah yang bertujuan untuk meningkatkan keterampilan berbahasa mahasiswa baik secara reseptif maupun produktif. Bertitik tolak dari tujuan tersebut maka kegiatan belajar yang harus fokus pada praktik langsung empat keterampilan berbahasa yaitu menyimak, membaca, berbicara dan menulis (Anonymous, 2011:171). Dengan fokus kegiatan tersebut, maka perlu sarana penunjang berupa LKM untuk memfasilitasi apa yang dilakukan mahasiswa dalam kelas.

LKM yang bisa mendukung keterlaksanaan pembelajaran PKBI tentunya adalah LKM yang berisi kegiatan-kegiatan produktif dalam frame empat aspek keterampilan berbahasa yaitu menyimak, membaca, berbicara, dan menulis. Kegiatan berbahasa dalam mata kuliah PKBI bertitik tolak dari whole language yang mengajarkan konsep berbahasa sebagai satu kesatuan yang tidak dapat dipisahkan. Oleh karena itu dalam mata kuliah PKBI, kegiatan kebahasaan dan kesastraan hadir dalam menyimak, membaca, berbicara, dan menulis yang dilakukan secara terpadu, tidak terpisah.

\section{Karakter dan Pembentukannya}

Djahiri (2002) menyatakan bahwa tujuan pendidikan umum adalah untuk membentuk manusia seutuhnya, yaitu manusia yang bermoral tinggi; bersikap dan berperilaku baik; serta memiliki kemampuan kognitif dan keterampilan yang tinggi. Menurut Maufur (1998) pendidikan umum bertujuan untuk: (1) mengembangkan kepribadian siswa secara komprehensif; (2) mempersiapkan siswa agar bertanggung jawab pada diri sendiri, keluarga, masyarakat, bangsa, dan Tuhannya; (3) bertanggung jawab pada pengembangan warga negara secara umum meliputi aspek sosial, moral, emosional dan intelektual secara terintegrasi; (4) membantu peserta didik hidup mandiri. Sementara itu Sumaatmadja (2002: 93-94) menyimpulkan bahwa tujuan pendidikan umum di Indonesia dalam Ketetapan MPR Nomor II/MPR/1988 itu sangat rinci yaitu meliputi aspek kognitif, afektif, dan psikomotor. Aspek koginitif pendidikan umum meliputi: kecerdasan, inovatif dan kreatif.

Aspek afektif meliputi: beriman, bertaqwa, berbudi pekerti, berkepribadian, disiplin, tangguh, tanggung jawab, kesetiakawanan sosial, dan percaya diri. Aspek psikomotornya meliputi: bekerja keras, tangguh, terampil, sehat jasmani dan rohani. Dapat disimpulkan bahwa tujuan yang hendak dicapai adalah nalar intelektual, emosional, sosial dan spiritualnya sudah terangkum dalam aturan yang telah disepakati. Adapun sasaran yang hendak dicapai pendidikan umum menurut Sumaatmadja (2002: 104) adalah: (1) memberikan pengetahuan sebanyak-banyaknya kepada peserta didik, meliputi liberal art, filsafat, bahasa, matematika, dan pengetahuan alam; dan (2) membekali peserta didik dengan latar belakang budaya yang luas, yang memberikan peluang kepada 
mereka untuk memiliki wawasan yang memadai tentang dunia dengan kehidupannya.

Pendidikan umum memberikan landasan kuat kepada peserta didik untuk menjadi sumber daya manusia (SDM) yang tidak hanya berbicara tentang agama, melainkan berfikir, berperasaan, berkesadaran, bertindak, berperilaku dan beramal sesuai dengan agama yang dianut masing-masing. Pendidikan umum bertujuan "memanusiakan manusia" peserta didik, tidak boleh tidak wajib melandasi proses pelaksanaannya dengan moral yang bermakna seluas-luasnya (Mulyana, 1998). Pada proses pendidikan umum, moral itu wajib tercermin pada suasana pembelajaran - interaksi edukatif- pengembangan materi pembelajaran, penerapan metode dan strategi sampai dengan evaluasi yang diterapkan. Pada pelaksanaan pendidikan umum, moral itu menjadi jiwa, suasana, interaksi edukatif dan tujuannya. Pendidikan umum berupaya secara bermakna dan berkesinambungan menghasilkan SDM yang bermoral bagi semua konteks kehidupan dalam suasana dan kondisi apapun (Sumatmadja, 2002).

Pendidikan karakter ditempatkan sebagai landasan untuk mewujudkan visi pembangunan nasional, yaitu mewujudkan masyarakat berakhlak mulia, bermoral, beretika, berbudaya, dan beradab berdasarkan falsafah Pancasila. Hal ini sekaligus menjadi upaya untuk mendukung perwujudan cita-cita sebagaimana diamanatkan dalam Pancasila dan Pembukaan UUD 1945. Di samping itu, berbagai persoalan yang dihadapi oleh bangsa kita dewasa ini makin mendorong semangat dan upaya pemerintah untuk memprioritaskan pendidikan karakter sebagai dasar pembangunan pendidikan. Semangat itu secara implisit ditegaskan dalam Rencana Pembangunan Jangka Panjang Nasional (RPJPN) tahun 2005-2015, di mana Pemerintah menjadikan pembangunan karakter sebagai salah satu program prioritas pembangunan nasional. Upaya pembentukan karakter sesuai dengan budaya bangsa ini tentu tidak semata-mata hanya dilakukan di sekolah melalui serangkaian kegiatan belajar mengajar dan luar sekolah, akan tetapi juga melalui pembiasaan (habituasi) dalam kehidupan, seperti: religius, jujur, disiplin, toleran, kerja keras, cinta damai, tanggung-jawab, dan sebagainya. Pembisaan itu bukan hanya mengajarkan (aspek kognitif) mana yang benar dan salah, akan tetapi juga mampu merasakan (aspek afektif) nilai yang baik dan tidak baik serta bersedia melakukannya (aspek psikomotorik) dari lingkup terkecil seperti keluarga sampai dengan cakupan yang lebih luas di masyarakat. Nilai-nilai tersebut perlu ditumbuhkembangkan peserta didik yang pada akhirnya akan menjadi pencerminan hidup bangsa Indonesia. oleh karena itu, sekolah memiliki peranan yang besar sebagai pusat pembudayaan melalui pengembangan budaya sekolah (school culture).

Karakter diartikan sebagai sifat-sifat kejiwaan, akhlak, atau budi pekerti yang membedakan seseorang dari yang lain (Sulhan, 2010:1). Karakter juga bisa diartikan tabiat, yaitu perangai atau kebiasaan. Pendapat lain mengemukakan bahwa karakter adalah watak, sifat batin manusia yang mempengaruhi segenap pikiran dan tingkah laku atau kepribadian. Karakter sebagai suatu "moral excellence" atau akhlak dibangun di atas berbagai kebajikan (virtues) yang pada gilirannya hanya memiliki makna ketika dilandasi atas nilai-nilai yang berlaku dalam budaya (bangsa). Karakter bangsa Indonesia adalah karakter yang dimiliki 
warga negara bangsa Indonesia berdasarkan tindakan-tindakan yang dinilai sebagai suatu kebajikan berdasarkan nilai yang berlaku di masyarakat dan bangsa Indonesia. Oleh karena itu, Pendidikan Budaya dan Karakter Bangsa diarahkan pada upaya mengembangkan nilai-nilai yang mendasari suatu kebajikasehingga menjadi suatu kepribadian diri warga negara. Berbeda dari materi ajar yang bersifat "mastery", sebagaimana halnya suatu "performance content" suatu kompetensi, materi Pendidikan Budaya dan Karakter Bangsa bersifat "developmental". Perbedaan hakekat kedua kelompok materi tersebut menghendaki perbedaan perlakukan dalam proses pendidikan. Materi pendidikan yang bersifat "developmental" menghendaki proses pendidikan yang cukup panjang dan bersifat saling menguat (reinforce) antara kegiatan belajar dengan kegiatan belajar lainnya, antara proses belajar di kelas dengan kegiatan kurikuler di sekolah dan di luar sekolah.

Di samping persamaan dalam kelompok, materi belajar ranah pengetahuan (cognitive) yang dalam satu kelompok "developmental" dengan nilai, antara keduanya terdapat perbedaan yang mendasar dalam perencanaan pada dokumen kurikulum (KTSP), silabus, RPP, dan proses belajar. Materi belajar ranah pengetahuan/kognitif dapat dijadikan pokok bahasan sedangkan materi nilai dalam Pendidikan Budaya dan Karakter Bangsa tidak dapat dijadikan pokok bahasan karena mengandung risiko akan menjadi materi yang bersifat kognitif. Oleh karena itu dalam pengembangan materi Pendidikan Budaya dan Karakter Bangsa sikap menyukai, ingin memiliki, dan mau menjadikan nilai-nilai tersebut sebagai dasar bagi tindakan dalam perilakukehidupan peserta didik sehari-hari merupakan persyaratan awal yang mutlak untukkeberhasilan Pendidikan Budaya dan Karakter Bangsa. Proses pembelajaran Pendidikan Budaya dan Karakter Bangsa dilaksanakan melalui proses belajar aktif. Sesuai dengan prinsip pengembangan nilai harus dilakukan secara aktif oleh peserta didik (dirinya subyek yang akan menerima, menjadikan nilai sebagai miliknya dan menjadikan nilai-nilai yang sudah dipelajarinya sebagai dasar dalam setiap tindakan) maka posisi peserta didik sebagai subyek yang aktif dalam belajar adalah prinsip utama belajar aktif. Oleh karena itu, keduanya saling memerlukan.

Karakter yang kuat hanya bisa dimiliki seseorang melalui proses pembiasaan yang bisa ditempuh dengan berbagai cara. Hidayatullah (2009) menyatakan bahwa karakter siswa bisa dibentuk dengan jalan keteladanan dan pembiasaan. Keteladanan mengandung makna bahwa pada saat melakukan pembelajaran seorang pendidik merupakan model bagi peserta didiknya. Artinya dosen dalam sebuah mata perkuliahan harus mampu menjadi teladan bagi mahasiswa dalam bertindak, berucap, maupun bertingkah laku. Pembiasaan mengandung pengertian pembinaan terhadap karakter dilakukan secara terus menerus melalui tugas-tugas mandiri dengan konsekwensi logis tertentu sebagai kontrak yang bersifat pasti terhadap perkuliahan. Tentunya konsekuensi logis tersebut harus berupa punishment positif yang tidak menjatuhkan mental tetapi mampu memaksa mahasiswa yang bersangkutan untuk menjalankan pekerjaannya sehingga terjadilah pembiasaan disiplin dan bertanggung jawab. 


\section{Lembar Kegiatan Mahasiswa Berbasis Inquiry}

Standar Kompetensi Lintas Kurikulum Nomor 9 di KBK menyebutkan bahwa mahasiswa dapat menunjukkan motivasi dan percaya diri dalam belajar, mampu bekerja secara mandiri, dan mampu bekerjasama dengan orang lain. Untuk memenuhi harapan tersebut, penggunaan LKM dalam kegiatan belajarmengajar mutlak dilakukan. Menurut Depdikbud (1995:21) LKM merupakan terjemahan dari students worksheet (merupakan suatu lembaran bukan buku-buku) yang berisi pedoman bagi mahasiswa untuk melakukan kegiatan secara terprogram. Ahmadi menyatakan bahwa penggunaan LKM dalam kegiatan belajar-mengajar bertujuan untuk: (1) mengaktifkan mahasiswa dalam belajar; (2) membantu mahasiswa mengembangkan dan menemukan konsep berdasarkan pendeskripsian hasil pengamatan dan data yang diperoleh dalam eksperimen; (3) melatih mahasiswa menemukan konsep melalui pendekatan keterampilan proses; (4) membantu dosen merencanakan kegiatan pembelajaran yang tepat berdasarkan karakteristik mahasiswa; dan (5) membantu dosen menyiapkan secara tepat dan cepat kegiatan pembelajaran, sehingga LKM yang telah dibuat dapat digunakan pada tahun ajaran berikutnya (Husna, 2004: 21).

LKM terbagi menjadi dua jenis yaitu LKM eksperimen dan LKM non eksperimen (Juariyah, 1999:20). LKM eksperimen digunakan untuk membimbing mahasiswa dalam kegiatan-kegiatan eksperimen yang berlangsung di laboratorium sedangkan LKM noneksperimen adalah LKM yang digunakan untuk kegiatankegiatan penemuan konsep yang disajikan dalam pertemuan-pertemuan pembelajaran di kelas. Yang dimaksud di kelas bukan hanya terpatok pada ruang dan jam tertentu melainkan bisa juga berupa tugas mandiri yang dikerjakan di luar jam tatap muka dengan dosen. LKM yang akan digunakan pada penelitian ini termasuk pada golongan LKM noneksperimen. Jika LKM eksperimen berisi petunjuk kegiatan, maka LKM noneksperimen berisi pertanyaan arahan, review, dan langkah kegiatan penemuan konsep serta penerapan konsep tersebut. Menemukan (inquiri) merupakan salah satu prinsip pembelajaran yang ada pada pendekatan kontekstual. Menurut Nurhadi (2002:12) dalam pendekatan kontekstual pengetahuan yang diperoleh siswa diharapkan bukanlah hasil dari mengingat-ingat seperangkat fakta tetapi dari hasil menemukan sendiri. Guru harus merancang pada kegiatan yang merujuk pada kegiatan menemukan, apapun materinya. Dalam menemukan ini siswa boleh berpedoman dalam buku tapi tidak sepenuhnya turut dengan apa yang dikatakan oleh buku.

Siklus yang diikuti oleh siswa dalam menemukan adalah: (1) observasi; (2) bertanya; (3) mengajukan dugaan; (4) pengumpulan data; dan (5) penyimpulan (Suyanto 2003: 9). Bertitik tolak dari penjelasan tentang LKM dan Inquiry di atas dapat disimpulkan bahwa LKM yang berbasis inquiry adalah LKM yang menuntun mahasiswa untuk menemukan pengetahuan sendiri berdasarkan proses inquiry. Dengan demikian LKM berbasis inquiry memuat langkah-langkah inquiry yang secara garis besar adalah: observasi, bertanya, mengajukan dugaan, pengumpulan data, dan penyimpulan.

\section{METODE PENELITIAN}


Penelitian ini bertujuan untuk: (1) mendeskripsikan perencanaan pembelajaran dengan menggunakan LKM terbimbing berbasis inquiry pada mata kuliah PKBI untuk mengembangkan karakter mahasiswa PGSD IKIP PGRI Madiun; (2) mendeskripsikan pelaksanaan pembelajaran Mata Kuliah PKBI dengan menggunakan LKM terbimbing berbasis inquiry untuk mengembangkan karakter mahasiswa PGSD IKIP PGRI Madiun; dan (3) mendeskripsikan perkembangan karakter mahasiswa PGSD IKIP PGRI Madiun setelah penggunaan LKM terbimbing berbasis inquiry pada matakuliah PKBI. Bertitik tolak dari tujuan tersebut maka penelitian ini mengambil tempat di kelas PKBI semester 2 Prodi PGSD IKIP PGRI MADIUN. Sedangkan rancangan penelitian yang digunakan adalah penelitian tindakan kelas (PTK). Alur PTK yang dilaksanakan dalam penelitian ini diilustrasikan pada Bagan 1.

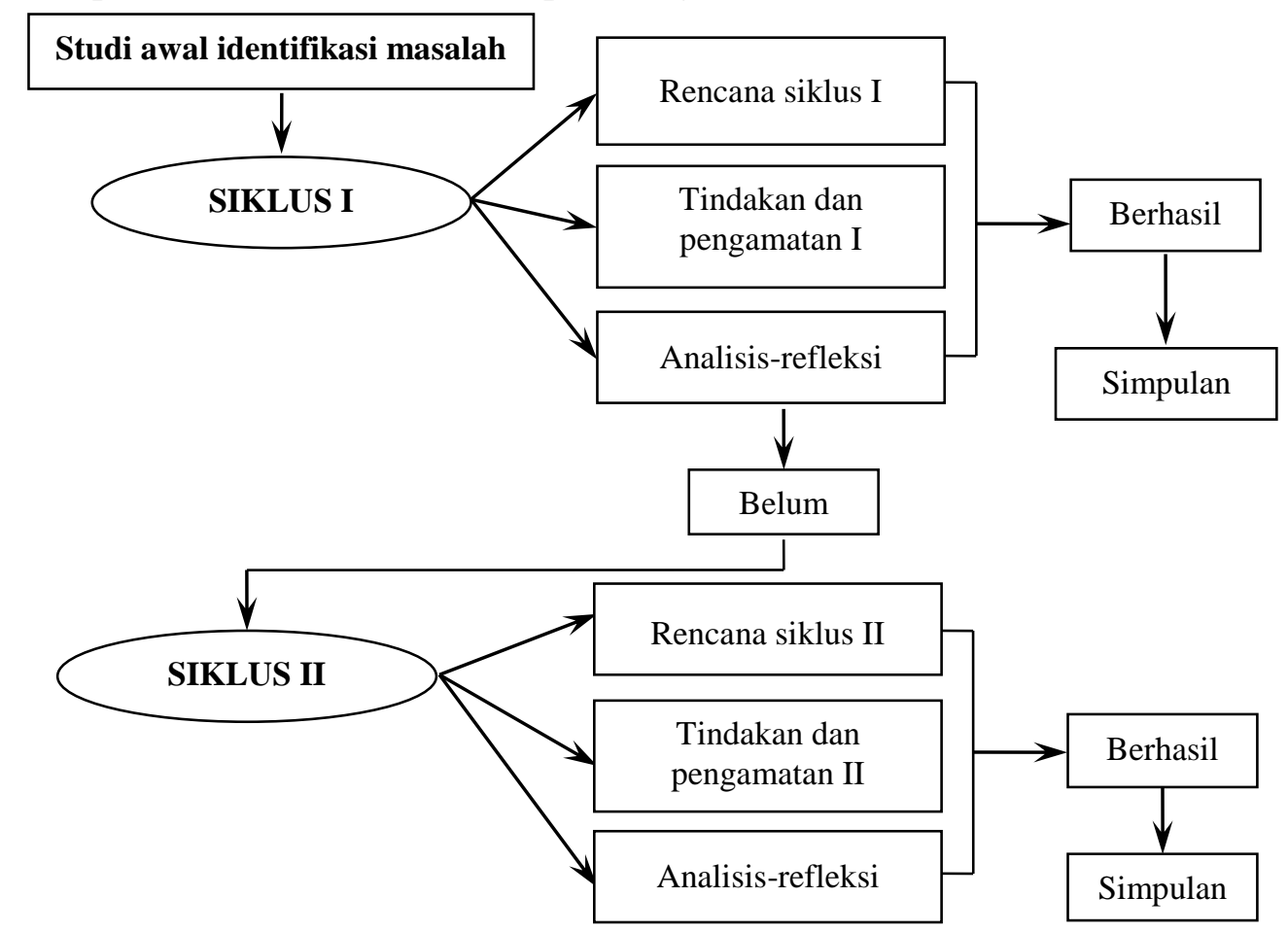

Bagan 1 Alur Penelitian Tindakan Kelas (Adaptasi Arikunto, 1996)

Data yang digunakan dalam penelitian ini adalah data tentang RPP dengan teknik pengambilan data dokumentasi dan instrumen penelitian peneliti itu sendiri, data pelaksanaan pembelajaran dengan teknik pengambilan data observasi langsung dan instrumen penelitian catatan lapang, data tentang perkembangan karakter dengan instrumen penelitian berupa angket dan lembar ceklish. Untuk menjawab rumusan masalah, data dianalisis dengan cara deskriptif kuantitatif sehingga detil masalah dan penyelesaiannya akan terlihat jelas. Perkembangan karakter mahasiswa yang diukur meliputi aspek kedisiplinan dan keproaktifan. Kedisiplinan diukur melalui ketepatan mahasiswa datang, ketepatan mengumpulkan tugas, dan ketepatan dalam proses penyelesaian tugas. Sedangkan keproaktifan dilihat dari jumlah buku sumber yang dibaca, dan partisipasi aktif mahasiswa dalam proses cros cek yang dilakukan dengan teknik brain storming. 
Penanaman karakter dianggap berhasil jika $70 \%$ mahasiswa mampu mencapai standar minimal ukuran sebesar $80 \%$ dari aspek yang diukur.

\section{HASIL PENELITIAN}

\section{Pratindakan}

Pada proses pratindakan dosen melakukan observasi awal terhadap proses perkuliahan yang berlangsung secara klasikal dengan teknik diskusi yang kemudian dilanjutkan dengan ceramah dan praktik. Hasil pengamatan menunjukkan bahwa mahasiswa yang aktif diskusi adalah mahasiswa yang berada pada posisi duduk 2 deret terdepan sementara yang lain menjadi pendengar setia atau melakukan kegiatan lain seperti mencorat-coret kertas, membuat gambar dan bermain-main dengan rambut. Praktik yang dilakukan tidak mampu mengcover jumlah mahasiswa yang besar sehingga hanya beberapa mahasiswa yang dipanggil secara random yang melakukan praktik sementara yang lain hanya melihat praktik yang dilakukan oleh temannya yang dikomentari oleh dosen. Banyak mahasiswa yang menjawab belum ketika dosen menagih tugas yang diberikan minggu lalu. Setelah dosen membeberkan perjanjian awal tentang tugas seluruh mahasiswa pada kelas yang bersangkutan mengumpulkan tetapi setelah diperiksa pada kenyataannya tugas dibuat secara asal-asalan.

\section{Siklus 1}

Bertitik tolak dari temuan pada pratindakan direncanakan tindakan siklus 1 menggunakan LKM dalam mata kuliah PKBI. Siklus satu berlangsung selama dua kali pertemuan. Pertemuan pertama dosen memberikan LKM yang harus dikerjakan oleh mahasiswa lengkap dengan lembar perjanjian, sumber yang harus dibaca, alternatif sumber bacaan, serta lembar refleksi. Pengerjaan LKM yang pertama dilakukan secara berkelompok. Satu kelompok terdiri dari 3 orang mahasiswa. Pada lembar refleksi, mahasiswa berhak menuliskan perasaannya serta mengevaluasi teman satu tim. Evaluasi berisi tentang pendapat mahasiswa terhadap persentasi kerja anggota lain serta kontribusi dirinya terhadap kelompok.

Pertemuan kedua siklus satu, dilakukan cros cek oleh dosen tentang pendapat masing-masing kelompok. Jika terjadi silang pendapat, maka dosen berfungsi sebagai penengah dan meluruskan pendapat yang kurang tepat. Pada saat kros cek sebagaian besar mahasiswa aktif terlibat untuk mempertahankan pendapat dan temuan kelompoknya serta hasil analisis yang sudah mereka lakukan. Tetapi ada beberapa mahsiswa yang dari awal perkuliahan tidak proaktif tetap diam dan hanya menonton jalannya cros cek dengan teknik brain storming kemudian hanya mencatat hasil pasti dari proses tersebut. Hal ini menjadi catatan bagi peneliti. Hasil analisis data setelah proses tindakan siklus satu selesai dapat dilihat dari Tabel 1.

Tabel 1 Persentase Hasil Tindakan Siklus 1

\begin{tabular}{clcc}
\hline No & \multicolumn{1}{c}{ Aspek yang Diukur } & Persentase & Keterangan \\
\hline 1 & Ketepatan datang & $90 \%$ & Tuntas \\
2 & Ketepatan mengumpulkan tugas & $70 \%$ & Tidak Tuntas \\
3 & Ketepatan proses pengerjaan & $60 \%$ & Tidak Tuntas
\end{tabular}




\begin{tabular}{cccc}
\hline No & Aspek yang Diukur & Persentase & Keterangan \\
\hline 4 & Keaktifan dalam brain storming & $65 \%$ & Tidak Tuntas \\
5 & Jumlah buku yang dibaca & $70 \%$ & Tidak tuntas \\
\hline
\end{tabular}

Setelah proses siklus satu berakhir, peneliti melakukan konsultasi dan diskusi dengan rekan sejawat serta dosen yang lebih senior untuk menganalisis kekurangan siklus 1 sekaligus merencanakan kegiatan pada siklus 2. Dari hasil analisis dan refleksi diperoleh kesimpulan bahwa kelemahan proses siklus satu terletak pada: (1) masih ada mahasiswa yang belum terlibat secara proaktif dalam pembelajaran di kelas pada saat brainstorming; dan (2) refleksi pada LKM belum mencerminkan partisipasi setiap mahasiswa dalam mengikuti perkuliahan sebab ada kemungkinan beberapa mahasiswa tetap menjadi angka ikut dalam kelompok, hanya saja teman 1 kelompok melindungi dengan alasan solidaritas. Sebenarnya konsep solidaritas tersebut bagus jika solidaritas dilakukan dalam hal kebaikan tetapi jika melindungi yang salah, ini justru menjadi bentuk karakter yang buruk.

Bertitik tolak pada hal tersebut maka pada pelaksanaan siklus dua direncanakan bahwa pengerjaan tugas akan dilakukan secara individu dan terkontrol dalam kelas. Kemudian secara random tugas yang diberikan pada mahasiswa yang satu dengan yang lain berbeda, artinya tidak seluruh tugas yang diberikan kepada mahaiswa berbeda tetapi ada kelompok mahasiswa yang mengerjakan tugas pertama, ada yang kedua, maupun ketiga dengan waktu tertentu. Tugas-tugas tersebut saling berkaitan. Beberapa mahasiswa yang menjadi catatan peneliti, dipaksa untuk berpendapat dengan cara ditunjuk melalui permainan sehingga mahasiswa yang bersangkutan tidak merasa tertekan atau ditandai oleh dosen.

Selain itu untuk mempertahankan yang lain juga tetap proaktif, disediakan ceklis berupa turus untuk melihat persentase dan intesitas keterlibatan mahasiswa. Turus tersebut ditampilkan pada LCD sehingga pengamatan bisa berlangsung secara obyektif. Selain itu tampilan turus pada LCD mengajarkan keterbukaan penilaian kepada mahasiswa. Dengan demikian mahasiswa dapat melihat sejauh mana dia dianggap aktif. Diinformasikan kepada kelas bahwa salah satu faktor yang akan mempengaruhi keberhasilan mahasiswa adalah turus persentase keaktifan. Fungsi lain yang bisa dilihat pada penggunaan turus adalah tercovernya praktik wicara untuk mahasiswa secara langsung.

\section{Siklus 2}

Proses siklus 2 diperpanjang menjadi $3 \mathrm{x}$ pertemuan sebab tugas mahasiswa yang semula dikerjakan di rumah disetting dikerjakan dalam proses pembelajaran di kelas dan secara individu sehingga secara otomatis dibutuhkan penambahan waktu. Selain itu pada siklus dua dimungkinkan adanya cros cek yang lebih detil. Pada pertemuan pertama, dosen mengecek persiapan mahasiswa untuk kegiatan yang sudah diinfokan minggu lalu. Pengecekan dilakukan dengan tujuan untuk mengetahui berapa jumlah buku sumber yang dibawa oleh masingmasing mahasiswa serta keberagaman jenis buku sumber yang akan digunakan. Selanjutnya proses pengerjaan LKM dimulai dan mahasiswa mengerjakan jobnya secara individu. Dosen berkeliling untuk melihat bagaimana mahasiswa mampu 
menemukan jawaban dengan teknik membaca cepatnya. Selain itu dosen memastikan mahasiswa satu dengan yang lain bekerjasama untuk menjawab pertanyaan yang ada. Setelah batas waktu yang ditentukan habis, dosen menghentikan pengerjaan LKM kemudian mengintruksikan kepada mahasiswa untuk berkelompok sesuai dengan job yang diterima, selanjutnya pekerjaan dalam kelompok tersebut ditukarkan dan proses brain storming dalam kelompok dilakukan.

Pada pertemuan kedua, kegiatan diawali dengan penginformasian kegiatan dari dosen. Setelah itu, dosen memfasilitatori brain storming kelas dan menampilkan tabel turus cros cek keproaktifan kepada mahasiswa serta menurusnya secara langsung. Mahasiswa yang masih menunjukkan sikap tidak proaktif diberikan kesempatan berpartisipasi dengan cara ditunjuk dengan permainan terarah untuk pertanyaan yang bersifat mudah. Pada pertemuan ketiga proses cros cek tetap berlangsung kemudian perkuliahan diakhiri dengan penyimpulan. Hasil tindakan siklus 2 dapat dilihat dari Tabel 2.

Tabel 2 Persentase Hasil Tindakan Siklus 2

\begin{tabular}{clll}
\hline No & \multicolumn{1}{c}{ Aspek yang Diukur } & Persentase & Keterangan \\
\hline 1 & Ketepatan datang & $100 \%$ & Tuntas \\
2 & Ketepatan mengumpulkan tugas & $100 \%$ & Tuntas \\
3 & Ketepatan proses pengerjaan & $85 \%$ & Tuntas \\
4 & Keaktifan dalam brain storming & $90 \%$ & Tuntas \\
5 & Jumlah buku yang dibaca & $80 \%$ & Tuntas \\
\hline
\end{tabular}

\section{E. PEMBAHASAN}

Dari hasil penelitian baik pada siklus 1 maupun 2 diketahui bahwa terjadi perubahan yang signifikan dalam hal ketepatan kedatangan mahasiswa, ketepatan dalam mengumpulkan tugas, proses pengerjaan, partisipasi serta jumlah buku yang dibaca oleh mahasiswa untuk mengerjakan tugas tersebut secara persentase kenaikan hasil tersebut, dapat dilihat pada Bagan 2.

Dari data di atas terlihat bahwa pada aspek kedisiplinan subaspek ketepatan datang mahasiswa menunjukkan perubahan dari $90 \%$ pada siklus 1 menjadi $100 \%$ pada siklus 2 . Untuk subaspek ketepatan dalam mengumpulkan tugas dari $70 \%$ pada siklus 1 menjadi $100 \%$ pada siklus 2. Subaspek ketepatan dalam proses pengerjaan $60 \%$ pada siklus 1 dan $80 \%$ pada siklus 2 . Hal yang sama juga terjadi pada aspek proaktif subaspek keaktifan dalam brain storming dari $65 \%$ pada siklus 1 naik drastis menjadi $90 \%$ pada siklus 2 . Pada subaspek jumlah buku yang dibaca dari $70 \%$ menjadi $80 \%$.

Hal ini menunjukkan bahwa penerapan LKM dapat memperbaiki karakter mahasiswa. Namun yang perlu diingat karena karakter tidak semata-mata hanya pada satu, dua atau tiga hari saja melainkan melekat seumur hidup maka proses pembelajaran ini harus dilaksanakan secara kontinyu dan terus menerus sehingga menjadi kebiasaan positif. 


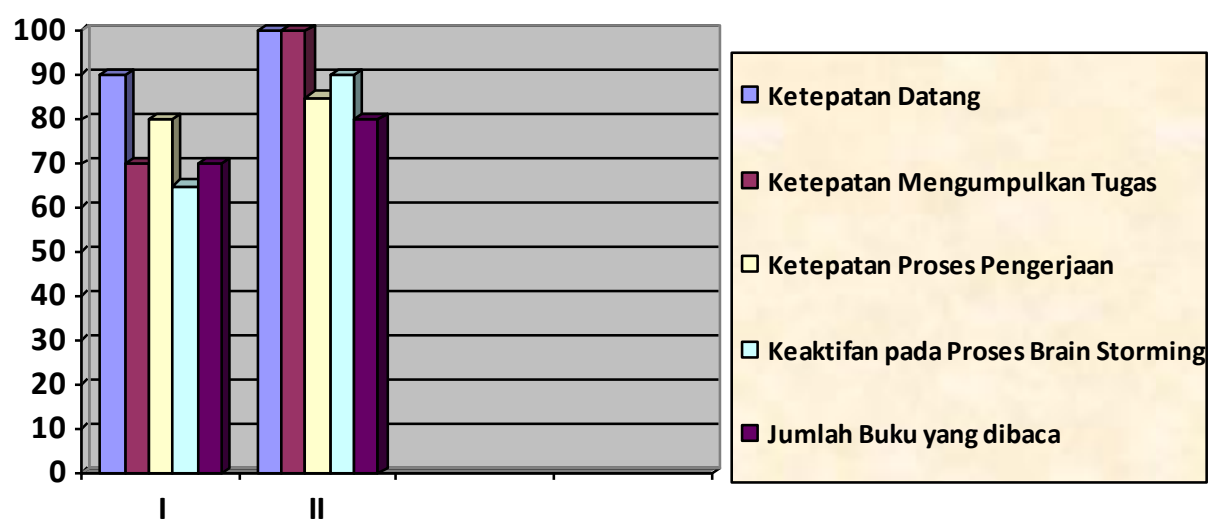

\section{Bagan 2 Rekap Data Hasil Penelitian Siklus 1 dan 2}

Selain faktor penerapan LKM, faktor penting lain yang menyebabkan penelitian ini berhasil terletak pada cara menerapkan LKM yang benar-benar mengikuti prosedur terbimbing dan konsekwensi logis yang dijalankan secara nyata, serta motivasi dari dalam diri mahasiswa untuk bisa berubah. Sehingga sangat penting untuk menyentuh aspek motivasi dalam pembentukkan karakter positif.

\section{F. KESIMPULAN DAN SARAN}

Berdasarkan permasalahan yang diajukan dan pembahasan dalam penelitian ini diperoleh kesimpulan, yakni: (1) perencanaan penggunaan LKM dalam upaya mewujudkan pembentukan karakter dilakukan dengan sangat terencana namun fleksibel sehingga dapat meng-handle masalah-maslah tidak terduga yang timbul dalam proses pembelajaran; (2) pelaksanaan pembelajaran dengan menggunakan LKM harus dilakukan secara terbimbing dan konsisten dalam artian aturan dan konsekwensi logis yang tertera dalam LKM betul-betul dijalankan sehingga efektif untuk mengaktivasi mahasiswa; dan (3) LKM yang digunakan secara benar, terbukti mampu menanamkan karakter kepada mahaiswa sebagai peserta didik.

Adapun saran yang bisa diajukan dalam penelitian ini adalah penggunaan pembelajaran yang berbasis karakter harus dilakukan secara kontinyu dan konsisten sehingga karakter tidak hanya muncul pada saat pembelajaran berlangsung melainkan melekat sebagi suatu ciri positif dari individu yang bersangkutan 


\section{DAFTAR RUJUKAN}

Arikunto, S. dkk. 2006. Penelitian Tindakan Kelas. Jakarta: Bumi Aksara.

Dahar, R.W. 1998. Teori-Teori Belajar. Jakarta: Depdikbud

Hidayatullah, M. F. 2009. Membangun Insan Berkarakter Kuat dan Cerdas. Surakarta: Yuma Pustaka

Husna. Pedoman Pengembangan LKM. Jakarta: Erlangga

Juariyah. 1999. Penggunaan Lembar Kegiatan Siswa. Jakarta: Erlangga

Nur, M., dan Wikandari, P. R. 1998. Pendekatan-Pendekatan Konstruktivis dalam Pembelajaran. Surabaya: Unipress Unesa.

Nurhadi. 2002. Pendekatan Kontekstual (Contextual Teaching and Learning (CTL) Malang: Universitas Negeri Malang.

Sulhan, N.2010. Pendidikan Berbasis Karakter. Surabaya: PT. Jepe Press Media Utama. 